\title{
Molecular Mechanisms of the Floral Biology of Jatropha curcas: Opportunities and Challenges as an Energy Crop
}

\author{
Manali Gangwar and Jata Shankar*t \\ Genomic Laboratory, Department of Biotechnology and Bioinformatics, Jaypee University of Information Technology, \\ Waknaghat, India
}

OPEN ACCESS

Edited by:

Briardo Llorente,

Macquarie University, Australia

Reviewed by:

Toshiro lto,

Nara Institute of Science

and Technology (NAIST), Japan

Yaping Chen,

Chinese Academy of Sciences, China

*Correspondence:

Jata Shankar

manaligwr88@gmail.com;

jata_s@yahoo.com

tORCID:

Jata Shankar

orcid.org/0000-0003-4993-9580

Specialty section:

This article was submitted to Crop and Product Physiology,

a section of the journal

Frontiers in Plant Science

Received: 11 August 2019

Accepted: 21 April 2020

Published: 09 June 2020

Citation:

Gangwar M and Shankar J (2020) Molecular Mechanisms of the Floral Biology of Jatropha curcas:

Opportunities and Challenges as an

Energy Crop.

Front. Plant Sci. 11:609.

doi: $10.3389 /$ fpls.2020.00609
Fossil fuel sources are a limited resource and could eventually be depleted. Biofuels have emerged as a renewable alternative to fossil fuels. Jatropha has grown in significance as a potential bioenergy crop due to its high content of seed oil. However, Jatropha's lack of high-yielding seed genotypes limits its potential use for biofuel production. The main cause of lower seed yield is the low female to male flower ratio (1:25-10), which affects the total amount of seeds produced per plant. Here, we review the genetic factors responsible for floral transitions, floral organ development, and regulated gene products in Jatropha. We also summarize potential gene targets to increase seed production and discuss challenges ahead.

Keywords: Jatropha curcas, energy crop, transcriptome, biofuel, ABCDE model

\section{INTRODUCTION}

About 11 billion tons of oil is consumed worldwide each year for fuel. With this rate of oil consumption, we may soon exhaust the oil reservoir (Shafiee and Topal, 2009) ${ }^{2}$. Climate change is also greatly influenced by fossil fuel combustion. Therefore, sustainable and environmentally friendly alternative energy sources are needed. Jatropha curcas L (Euphorbiaceae) is a plant with potential for biodiesel production due to its high seed oil content (around 45-50\%) (Achten et al., 2008). Compared with other oil plants, Jatropha has its own merits, including an outstanding adaptability to varied environments, smooth propagation, and greater fruit and seed size. Furthermore, Jatropha grows well in the desert, adapts to drought conditions, has a short gestation period, and assists in soil conservation. Despite its advantageous properties for biodiesel production, Jatropha has some limitations that restrict its commercialization as an energy crop, such as low seed yield, inconsistent flowering and fruiting, and relatively expensive plantation maintenance. The significant factors influencing its potential as biofuel feedstock are the oil content in seeds, the number of seeds per tree, the number of fruits on each branch of the plant, and the number of branches per plant. Seed yield at each inflorescence is largely dependent on the number of female flowers. Jatropha's female to male flower ratio is quite small (1:25 to 1:30), which means that each inflorescence contains only about 10 to 12 female flowers (out of 300) that yield just 8 to 10 fruits. Therefore, a relatively small number of fruits are produced as compared to the total number of flowers (Kumar and Sharma, 2008). One way to increase the total seed yield in Jatropha would be to increase the number of female flowers per plant. In this context, we have discussed the genetic factors involved in the floral transformation, determination of sex, and floral growth of Jatropha curcas.

\footnotetext{
${ }^{1}$ https://www.ecotricity.co.uk/our-green-energy/energy-independence/the-end-of-fossil-fuels
} 


\section{BIOLOGY OF SEX DETERMINATION IN JATROPHA CURCAS}

Sex determination processes allow floral organ development in plants. The two processes for forming a unisexual flower are (i) emergence of only one type of sex organ (unisexual tissues) and (ii) initiation of stamen and pistil followed by an arrest or abortion of one sex organ, which results in the functional immaturity of either stamens or carpels. The developmental arrest step occurs at an immature stage well before sexual maturity is reached (Ainsworth, 1999, 2000; Kater et al., 2001). There are two modes of sex determination and development in Jatropha. One mode is the development of male flowers with early adolescence without any female primordia. The other mode is by aborting male tissues, which results in female flowers developing ( $\mathrm{Li}$ and $\mathrm{Li}, 2009$; Wu et al., 2011). The male flower is unisexual right from the start, whereas the female flower is bisexual until its sixth developmental phase. Because of this, an inflorescence has three types of flowering sites; (i) female flowering site, (ii) male flowering site, and (iii) middle flowering site where both males and females may develop. Though male tissue abortion occurs in female flowers during sexual differentiation, traces of male tissue may be found in mature females. However, when abortion of male tissues fails in a female flower, it develops as a male at the female flowering site. Such inflorescence is known as middle type inflorescence. Due to the number of female flowers formed at middle type inflorescence, variation in the total number of female flowers occurs. An inflorescence statistical analysis found $\sim 75$ percent of middle-type inflorescence and 0.09 percent of female flowers (Luo et al., 2007; Wu et al., 2011). For 18 female locations, Wu et al. (2011) found only seven female flowers. The female flowering sites and the sites occupied by middle-type inflorescence are important in increasing the number of female flowers. The presence of hermaphroditic flowers has also been recorded in Jatropha, showing structural similarity with female flowers but diffused stamens (Abdelgadir et al., 2010; Wu et al., 2011; Adriano-Anaya et al., 2016). A recent population analysis on Jatropha's floral diversity and sex expression has grouped accessions into gynoecious (having only females), androecious (having only males flowers), and andromonoecious (having both bisexual and male flowers) plants showing no correlation with their geographic location (Adriano-Anaya et al., 2016). Of the 103 accessions from 33 sites in southern Mexico, 93.2 percent were monoecious, while others were androgynomonoecious, androecious, or gynoecious (Figures 1A,B). It has been hypothesized that male development commences through suppression of females, which might be the result of male sterility mutation in gynomonoecious plants (Salvador-Figueroa et al., 2015; Adriano-Anaya et al., 2016). No gynomonoecious plants of Jatropha have been found. The possible explanation, according to Adriano-Anaya et al. (2016), is that gynoecious Jatropha plants derive from hermaphrodite ancestors through a one-step mutation.

Abbreviations: BRs, brassinosteroids; CTK, cytokinin; GAs, gibberellic acids; JAs, jasmonic acid; Jatropha, Jatropha curcas L.

\section{GENETIC FACTORS FOR VEGETATIVE TO A REPRODUCTIVE PHASE TRANSITION}

In floral initiation, the apical shoot meristem differentiates into an inflorescence. The induction of floral signaling is genetically controlled by floral integrator genes, such as $F T$ (FLOWERING LOCUS T), FLC (FLOWERING LOCUS C) and SOC1 (SUPPRESSOR OF OVEREXPRESSION OF CONSTANS 1). Ye et al. (2014) reported that JcFT (Jatropha Flowering locus $T$ ) overexpression caused early flowering by shortening the bolting time. Li et al. (2014) characterized FT in Jatropha, and data from its spatial expression showed higher expression in reproductive phases. The $L F Y$ gene has recently been identified and overexpressed in both Arabidopsis thaliana and Jatropha (Tang et al., 2016). During the early stages of flowering, they observed a higher expression of JcLFY (Jatropha LEAFY). Transgenics with $J C L F Y$ overexpression showed early flowering and increased transcript levels of floral meristem identity genes, such as JcAP1, JcAP3, JcSEP1, JcSEP3, and JcAG. In addition, cosuppression of $L F Y$ in Jatropha resulted in delayed flowering, abnormal floral flowers replaced by sepaloid organs, and an increased rate of floral abortion (Tang et al., 2016). Recently, the role of TFL1 homologs has been studied through the transgenic method, and their overexpression has resulted in delayed flowering due to reduced $A P 1$ and $F T$ gene expression (Karlgren et al., 2013; Li et al., 2017). In contrast, Li et al. (2014) reported higher expression of FT in Jatropha's reproductive phases and fruits. Circadian rhythms play an important role in the initiation of flowering. JcDof3, a plant-specific transcription factor with a conserved zinc finger (ZF) DNA-binding domain, is a circadian clock regulated gene. The C-terminal conserved region of Dof3 interacts with the F-box protein forming Dof3Fbox complex regulating the expression of $\mathrm{CO}$, a circadian clock regulating flowering gene (Yang et al., 2011). Foliar cytokinin (CTK) treatment upregulates genes GI, SOC1, and LFY, and inactivates genes COP1 and TFL1b that maintain a flowering signal which promotes flowering (Chen et al., 2014; Pan et al., 2014). Thus, the interplay between the circadian rhythm and hormones control flowering genes and phase transition to inflorescence meristem in Jatropha.

\section{MOLECULAR BASIS OF SEX DETERMINATION}

Jatropha is a monoecious plant in which female flowers are formed due to stamen abortion/suppression. Remains of female tissues are not observed in male flowers, though remains of aborted stamens (male tissues) are present at the base in female flowers. By analyzing Jatropha floral buds for gene expression, the SUPERMAN gene was observed to suppress male tissue and promote the development of female tissue (Gangwar et al., 2018). A recent study suggested that, in Arabidopsis, the SUPERMAN gene not only bridges floral organogenesis and floral meristem but also regulates 

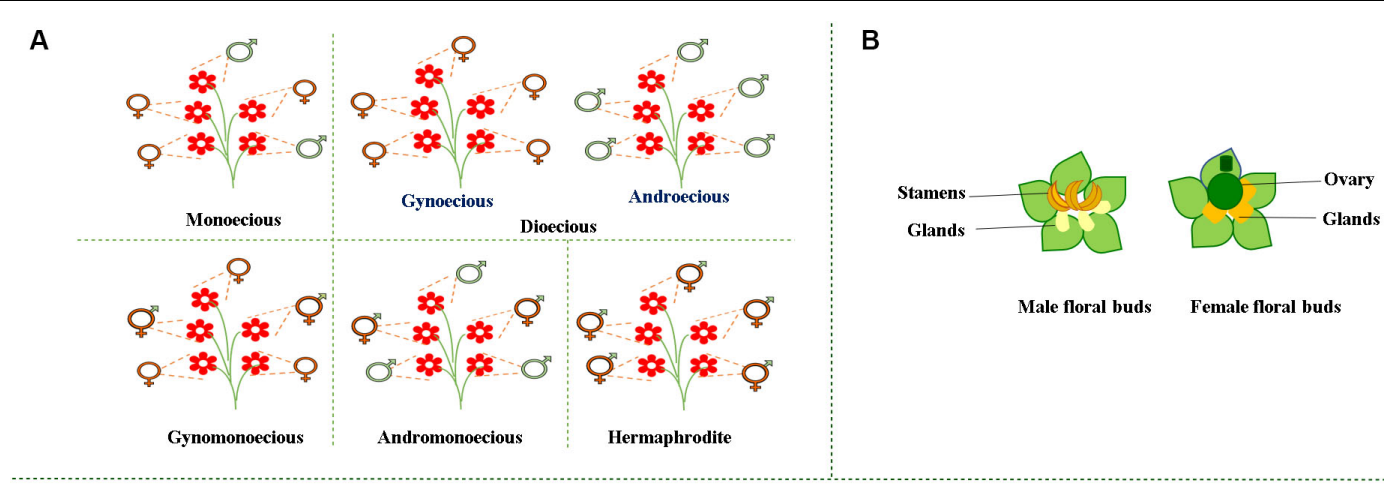

c

YUC1, YUC4, GA2OX, GA3OX, PI, $A P 3, D A D 1$, GASA4, C oxidase

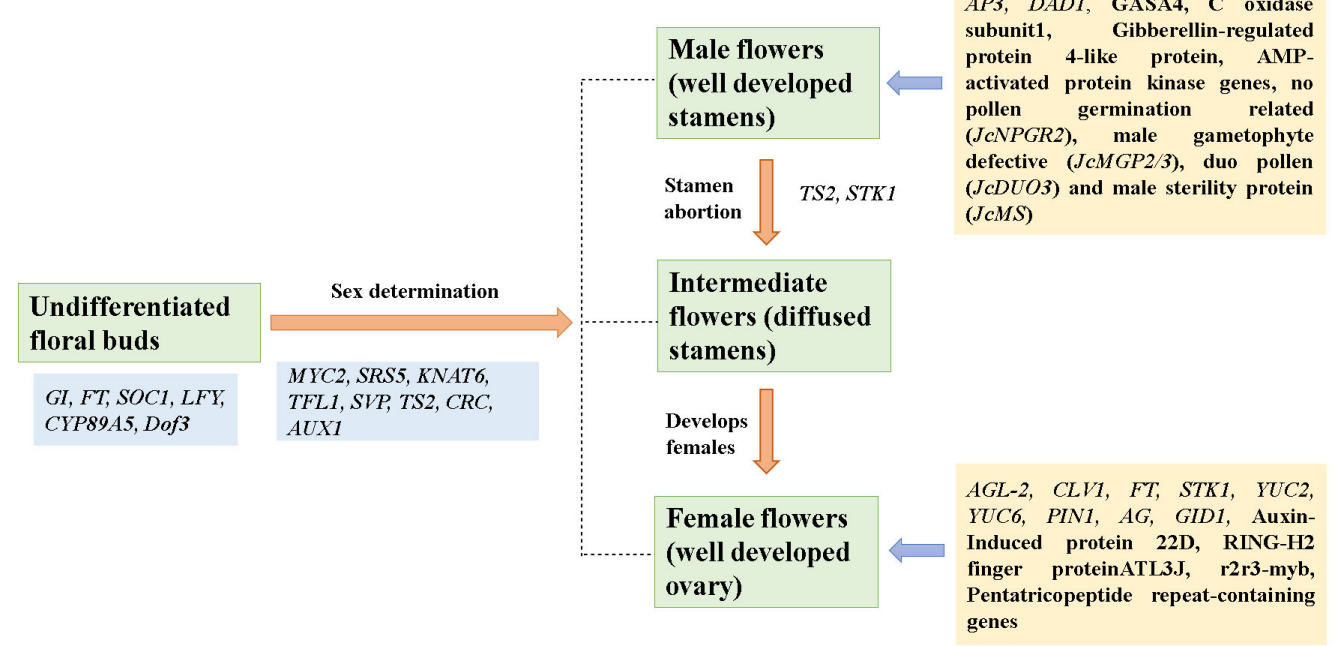

FIGURE 1 | (A) Diversified morphology of flowers. $\sigma^{7}$ Represents male flowers; ㅇ Represents female flowers; ợ Represents hermaphrodite flowers. (B) Morphology of male and female floral buds in Jatropha. (C) Key genes involved in the floral transition, sex determination, and reproductive organ development (GI-GIGANTEA; FT-FLOWERING LOCUS T; SOC1-SUPPRESSOR OF OVEREXPRESSION OF CONSTANS 1; LFY-LEAFY; CYP89A5-CYTOCHROME P450; SRS5-SHI-RELATED SEQUENCE 5; KNAT6-KNOTTED1-LIKE HOMEOBOX GENE 6; TFL1-TERMINAL FLOWER 1; SVP-SHORT VEGETATIVE PHASE; TS2-TASSELSEED2; CRC-CRABS CLAW; AUX1-Auxin transporter protein 1; STK1-SEEDSTICK; YUC1-Flavin-containing monooxygenase; YUC2/4/6-Indole-3-pyruvate monooxygenase; GA30x-Gibberellin 3-beta-hydroxylase; GA20ox-Gibberellin 20-oxidase; PI-PISTILLATA; AP3-APETALA3; DAD1-DEFECTIVE IN ANTHER DEHISCENCE 1; GASA4-Gibberellin-regulated protein 4 precursor; AGL2-AGAMOUS-LIKE 2; CLV1-CALVATA1; PIN1-PIN-FORMED 1; AG2-AGAMOUS-like protein 2; GID1-Gibberellin receptor protein).

auxin biosynthesis (Xu et al., 2018). Transcriptome analysis of Jatropha's floral buds showed reduced expression of the stamen development gene TASSELSEED 2 (TS2) that facilitated the growth of carpels (Chen et al., 2014). Transcriptomic analysis of different stages of male and female flower buds of Jatropha showed upregulation of CRABS CLAW (CRC) during development stages of female flowers. $C R C$, a $\mathrm{C} 2 \mathrm{C} 2$ YABBY zinc finger protein, is involved in the regulation of carpel fusion and growth, nectary formation, and floral meristem termination ( $\mathrm{Xu}$ et al., 2016; Gross et al., 2018). Genes encoding for inorganic phosphate transporter and ubiquitin carboxyl-terminal hydrolase were upregulated during female flower development and may contribute to embryo sac development (Xu et al., 2016). Further, upregulation of genes encoding for chlorophyll A/B-binding protein during initiation of carpel primordia may facilitate carpel differentiation. Genes encoding for Gibberellin-regulated protein 4-like protein, cytochrome c-oxidase subunit 1 (mitochondrial gene), and AMP-activated protein kinase, however, were upregulated during stamen development. Upregulation of genes encoding for RING-H2 finger protein ATL3J (E3 ubiquitin ligases), CLAVATA1 (receptor-like kinase), auxin-induced protein 22D, transcription factor R2R3-myb (regulating cell cycle genes and cytokinin signaling), and AGAMOUS-LIKE-20 (MADS-box genes) have been identified during the late stage of female flower development, which may facilitate the maturation of female flower (Alvarez and Smyth, 1999; Pelaz et al., 2000; Makkena et al., 2012; Xu et al., 2016). In both male and female flower buds, genes such as ARP1 (Auxin repressed protein), X10A (auxin-induced protein), and GID1 (gibberellin receptor protein) were upregulated (Xu et al., 2016). The role of $J c F T$, a florigen and a key flowering pathway regulator in Jatropha showed significantly high transcript levels in female flowers (Li et al., 2014). Another transcriptomic study 
identified MYC2, TS2, KNAT6, SVP, TFL1, and SRS5 as sex determination regulators in J. curcas (Chen et al., 2017). The suppression of nodulin MtN3 or LESS ADHERENT POLLEN (LAP3) resulted in small anthers, sterile pollens, and abortion of female flowers in Oryza sativa, Vitis vinifera, and Medicago truncatula (Chu et al., 2006; Ramos et al., 2014). In Pisum sativum $L$, carpel senescence has been induced as a result of increased lipoxygenase gene expression (Rodríguez-Concepción and Beltrán, 1995). Pentatricopeptide repeat-containing gene is expressed in the female embryo sac and restores the cytoplasmic male sterility in Jatropha (Bentolila et al., 2002; $\mathrm{Xu}$ et al., 2016). Key genes involved in the floral transition, sex determination and development of reproductive organs are shown in Figure 1C and Table 1. These studies shed light on how sex determination and differentiation occur in monoecious plants and how some of the genes expressed during floral differentiation suppress male flowering.

\section{ABCDE MODEL FOR SEX DIFFERENTIATION}

The ABCDE model is a scientific model that specifies the role of homeotic genes in the development of floral organs. Genes of the A class specify sepal development. The development of petals occurs by the combined effect of genes from the A and $\mathrm{B}$ classes. Both the B- and C-class genes are important for stamen growth. The carpel development and activity of ovules are determined by C-class and D-class genes, respectively. Recently, E-class genes were discovered to play a role in the development of carpel and ovary (Pelaz et al., 2000; Honma and Goto, 2001). A-, B-, C-, D-, and E-class genes are transcription factors with conserved DNA binding domains known as the MADS-box family and are involved in floral organogenesis regulation (Parěnicová et al., 2003; Chen et al., 2019). PERIANTHA (PAN), a bZIP transcription factor, activates $A G$, a C-class MADS-box protein that regulates floral organ numbers and whorl patterning (Maier et al., 2009). In Elaeis guineensis, the mutants AP3 and PISTILLATA (PI) inhibited male tissues. $A G 2$ has a mixed $\mathrm{C} / \mathrm{D}$ function gene, and its expression has been observed in ovule primordia and carpel of Arabidopsis and Elaeis guineensis, respectively (Favaro et al., 2003; Adam et al., 2007). FLORAL BINDING PROTEIN 11 (FBP11), a D-class gene, determines the formation of ovules in cucumbers (Favaro et al., 2003). An increase in the C-class gene transcription level arrests the development of sexual organs in monoecious plants, such as Liquidambar styraciflua L and Rumex acetosa L (Ainsworth, 2000). B-and $\mathrm{C}$-class genes are regulated at a sex locus by a genetic switch that further controls the development of male or female flowers in Populus trichocarpa (Leseberg et al., 2006). B-class genes $P I$ and AP3 have been identified in the formation of stamen in Jatropha. A- and C-class gene $A G$ and D-class gene SEEDSTICK1 (STKI) have been reported for carpel development and maturation (Hui et al., 2017). Thus, the ABCDE model helps to understand the floral differentiation in Jatropha.

\section{ROLE OF HORMONES IN SEX DETERMINATION}

The process of flower development and sex determination is regulated by the interplay of endogenous hormones (auxins, cytokinins, gibberellins, abscisic acids, etc.). Auxin regulates sex determination in Jatropha. IAA enhanced female to male ratio from 1:27 to 1:23, and it also increased seed weight 3-fold (Joshi et al., 2011). Auxin biosynthesis and signaling are associated with genes such as ARFs, $A U X 1$, and Transport inhibitor response 1 (TIR1). Transcriptome analysis of Jatropha suggested that $A U X 1$ is responsible for sex determination. The main source of auxin production is through Trp-dependent auxin biosynthesis, which participates in embryo patterning and reproductive organ development (Chen et al., 2017). In this pathway, IAA is produced from indole-3-pyruvic acid by YUCCA (YUC), a flavindependent monooxygenase (Stepanova et al., 2008). During stamen primordia formation, auxin is produced locally by YUC1 and YUC4 followed by YUC2 and YUC6 genes at late stages of stamen development (Cheng et al., 2006; Cecchetti et al., 2008). In mature gynoecia, YUC4 and YUC8 genes were expressed in the style, whereas YUC2 was expressed in carpel valve tissues (Martínez-Fernández et al., 2014). Increased expression of $A R F$ $10 / 16 / 17 / 18$ leads to abnormalities in females and abortion of organs, resulting in fewer seed sets (Huang et al., 2016).

Gibberellic acids also contribute to the development of the stamens in monoecious plants. Exogenous application of GA on the inflorescences of Jatropha resulted in a 2-fold increase in female flowering. However, inflorescence branches were not affected. Hui et al. (2018) reported the altered endogenous CTK (increased) and GA (decreased) ratio due to exogenous GA application, which resulted in an increased proportion of female flowers. However, a higher concentration of GA caused withering of floral buds. $\mathrm{Hu}$ et al. (2017) isolated the JcGA2ox6 (Gibberellin oxidase) gene, which reduces the amount of endogenous GA4 (active gibberellin). They overexpressed JcGA2ox6 gene in Jatropha, which led to decreased inflorescence size, decreased male and female flowers, and decreased seed length in transgenic plants. There was a significant decrease in both seed weight and oil content. GA20ox and GA3ox have been observed in other studies to enhance the development of stamen, whereas the exogenous application of GA3 led to a restricted development of pistils, thus enabling the male to expand. GA treatment enhanced the development of stamens in monoecious females, and it resulted in bisexual flowers in monoecious plants. GASA4 protein functions in stamen differentiation. GID1, a positive GA signaling pathway regulator, controls Jatropha's female flowering (Roxrud et al., 2007; $\mathrm{Hu}$ et al., 2017). GA deficiency results in male sterility in plants. Therefore, GA allows the stamens to develop without affecting female flowers.

Paclobutrazol foliar application inhibits GA biosynthesis and promotes female flowering by suppressing no related pollen germination (JcNPGR2), male defective gametophyte (JcMGP2/3), duo pollen (JcDUO3), and male sterility protein (JcMS) genes, thus allowing female flowers to develop in Jatropha (Seesangboon et al., 2018). 
TABLE 1 | Key genes involved in the floral transition, sex determination, and reproductive organ development.

\begin{tabular}{|c|c|c|c|}
\hline \multicolumn{4}{|c|}{ Vegetative to reproductive stage } \\
\hline $\begin{array}{l}\text { 1-aminocyclopropane-1-carboxylate } \\
\text { synthase } 7 \text { (ACS7) }\end{array}$ & Cucumis sativus & Ethylene biosynthesis & Switzenberg et al., 2014 \\
\hline Agamous (AG) & Populus trichocarpa & MADS-box regulators of differentiation, Homeotic genes & Brunner et al., 2000 \\
\hline Dof3 & Arabidopsis thaliana & F-box protein regulates flowering time & Imaizumi, 2010 \\
\hline Flowering locus C (FLC) & Arabidopsis thaliana & Florigen signaling & Li et al., 2014 \\
\hline Flowering Locus $T(F T)$ & Arabidopsis thaliana & Florigen signaling & Li et al., 2014 \\
\hline GIGANTEA (G) & Arabidopsis thaliana & Circadian clock control and photoperiodism & Mizoguchi et al., 2005 \\
\hline LFY & Arabidopsis thaliana & Florigen signaling & Tang et al., 2016 \\
\hline Sepallata $(S E P 1 / 3)$ & Arabidopsis thaliana & Floral meristem identity genes & Pelaz et al., 2000 \\
\hline
\end{tabular}

\section{Genes associated with flowering sex determination}

Aborted microspores (AMS)

Agamous (AG2)

Arabidopsis thaliana; Capsicum

annuum L.

Elaeis guineensis

Arabidopsis thaliana

Elaeis guineensis

Apetala 3 (AP3)

ARF 10/16/17/18

ATL3J

Auxin induced protein (X10A)

Auxin repressed protein (ARP1)

Clavata1 (CLV1)

CRABS CLAW (CRC)

Cup-shaped cotyledon 2 (CUC2)

Defective in Tapetal development and

function 1 (TDF1)

Duo pollen (DUO3)

Floral binding protein 11 (FBP11)

Gibberellin receptor protein (GID1)

Less adherent pollen (LAP3)

Lonely guy (LOG)

Male gametophyte defective (MGP2/3)

No pollen germination related (NPGR2)

Pistillata $(P /)$

Seedstick1 (STKI)

Sporocyteless/nozzle (SPL/NZZ)

Superman (SUP)

Tasselseed 2 (TS2)

YUCCA (YUC1/2/4/6)

Elaeis guineensis
Arabidopsis thaliana

Zea mays

Arabidopsis thaliana

Nicotiana tabacum

Arabidopsis thaliana

Arabidopsis thaliana; Oryza sativa

Arabidopsis thaliana; Silene latifolia

Arabidopsis thaliana

Arabidopsis thaliana

Cucumis sativus

Oryza sativa

Oryza sativa, Vitis vinifera, Medicago Pollen development

truncatula

Oryza sativa

Arabidopsis thaliana

Arabidopsis thaliana

Arabidopsis thaliana

Arabidopsis thaliana

Arabidopsis thaliana

Zea mays

Arabidopsis thaliana

Pollen maturation
Pollen and anther development

Ovule primordia and carpel

Induces microsporogenesis, Embryo sac development

Development of male tissues

Female organ abortion

Embryo sac development

Stamen differentiation and embryo sac development

Peptide-receptor signaling

Carpel fusion and growth, forming nectary

Forms boundary between the organs and separates

organs with meristem

Pollen and anther development

Regulator of Male Germline and embryogenesis

Ovule formation

Stamen differentiation and embryo sac development

Maintains floral meristem activity and ovule development Yamaki et al., 2011

Pollen tube growth and pollen germination

A calmodulin-binding protein regulated pollen germination Golovkin and Reddy, 2003

Development of male tissues

Carpel development

Regulates anther cell differentiation

Suppresses stamen development

Stamen development by Pistil abortion

Stamen development
Ye et al., 2010; Guo et al., 2018

Favaro et al., 2003; Adam et al., 2007

Pelaz et al., 2000

Favaro et al., 2003; Adam et al., 2007

Huang et al., 2016

Xu et al., 2016

Xu et al., 2016

Nakamura et al., 2004; Xu

et al., 2016

Alvarez and Smyth, 1999

Gross et al., 2018

Li et al., 2010

Zhu et al., 2008

Brownfield et al., 2009

Favaro et al., 2003

Ueguchi-Tanaka et al.,

2007; Xu et al., 2016

Chu et al., 2006; Ramos

et al., 2014

Deng et al., 2010

Favaro et al., 2003; Adam

et al., 2007

Pinyopich et al., 2003

Liu et al., 2009

Prunet et al., 2017

Acosta et al., 2009

Stepanova et al., 2011

\begin{tabular}{|c|c|c|c|}
\hline \multicolumn{4}{|c|}{ ABCDE Model Genes } \\
\hline Pistillata $(P I)$ & Elaeis guineensis; Jatropha curcas & B-class, stamen development & $\begin{array}{l}\text { Favaro et al., 2003; Adam } \\
\text { et al., 2007; Hui et al., } 2017\end{array}$ \\
\hline Apetala 3 (AP3) & Elaeis guineensis; Jatropha curcas & B-class, stamen development & $\begin{array}{l}\text { Favaro et al., 2003; Adam } \\
\text { et al., 2007; Hui et al., } 2017\end{array}$ \\
\hline
\end{tabular}


TABLE 1 | Continued

\begin{tabular}{|c|c|c|c|}
\hline \multicolumn{4}{|c|}{ ABCDE Model Genes } \\
\hline Gene name & Plant spp. & Pathway/Association & References \\
\hline Agamous (AG) & Jatropha curcas; Populus trichocarpa & C-class, carpel differentiation & $\begin{array}{l}\text { Brunner et al., 2000; Hui } \\
\text { et al., } 2017\end{array}$ \\
\hline SEEDSTICK 1 (STKI) & Arabidopsis thaliana; Jatropha curcas & D-class, carpel maturation & $\begin{array}{l}\text { Pinyopich et al., 2003; Hui } \\
\text { et al., } 2017\end{array}$ \\
\hline Sepallata (SEP) & Arabidopsis thaliana; Jatropha curcas & E-class, male floral initiation & $\begin{array}{l}\text { Pelaz et al., 2000; Chen } \\
\text { et al., } 2019\end{array}$ \\
\hline
\end{tabular}

Jasmonic acids and brassinosteroids (BRs) are active in floral development together with stamen development, pollen maturation, and male fertility (Park et al., 2002; Ye et al., 2010). In staminate maize flowers, brassinosteroids promoted pistil abortion. AG controls the maturation and late stages of stamen development in Arabidopsis by regulating the biosynthesis of jasmonates (Ito et al., 2007). Reduced JA synthesis in Jatropha led to male abortion and downregulation of the genes DAD1 and LOX2. Arabidopsis, maize, and tomato mutants with suppressed jasmonate synthesis and brassinosteroid signaling resulted in male sterility (Li et al., 2005; Ye et al., 2010). The SPL/NZZ, Aborted Microspores (AMS) and Defective in Tapetal Development and Function 1 (TDF1) genes are regulated by BRs and are critical for anther and pollen development (Ye et al., 2010). Thus, BRs and JAs promote the development of male organs.

Foliar application of ethylene induced femininity in Jatropha. To synthesize ethylene, 1-aminocyclopropane-1-carboxylic acid oxidase 2 (ACO1) oxidizes ethylene intermediates. Transgenics plants that overexpressed ACO2 were male sterile due to suppressed stamens. Little to no activity of $A C O$ was observed in Arabidopsis, tomato, and tobacco during the development of anthers and pollens (Bartley and Ishida, 2007; Duan et al., 2008; Wang et al., 2010). These experiments have thus shown that ethylene promotes feminism in plants.

Studies have been conducted to see the effect of foliar cytokinin application on the inflorescences. It has been found that 29.99 percent of the total flowers were females in treated inflorescences as compared to 6.96 percent in control. In treated inflorescence, a 4-5-fold increase in the number of seeds was observed but the fruiting rate, seed weight, and oil content decreased (Pan and Xu, 2011; Pan et al., 2014; Chen et al., 2014).

Transcriptomic analysis of Jatropha inflorescences treated with cytokinin revealed that genes involved in the initiation of flowers, such as GI, SOC1, and LFY, and the CYP89A5 gene involved in the development of inflorescences were induced, whereas the $A P 1, A P 2, P I, A G$, and SEP1-3 genes were downregulated (Chen et al., 2014; Pan et al., 2014). These developments allowed more time for inflorescence meristems to generate floral primordia. A vital increase in the number of flowers was noted due to CUC1 upregulation. Application of BA (6-Benzylaminopurine) increased the rate of cell division in inflorescence meristem due to the upregulation of Cyclin-3-1 (CycD3;1/2) and Cyclin-dependent protein kinase $247(C y c A 3 ; 2)$ genes. Li et al. (2010) observed an increase in the number of flowers with an enlarged inflorescence and floral meristem in transgenic Arabidopsis overexpressing CK (cytokinin) biosynthetic gene (AtIPT4). Fewer flowers were observed at each inflorescence due to the overexpression of the CKX gene (Werner and Schmülling, 2009). Loss-of-function mutation of LONELY GUY (LOG) (encodes for CK-activating enzyme) gene of rice led to the significant decrease in the number of floral organs (Kurakawa et al., 2007). Chen et al. (2014) reported that BA treatment decreased the expression of TS2, which suppresses carpel in maize, leading to increased female to male flower ratios in Jatropha (Acosta et al., 2009).

\section{CHALLENGES}

Genomic studies on flowering of Jatropha and phenotypic changes following the application of PGRs (Plant Growth Regulators) showed an opportunity to increase female flowering, which is one of the aspects for increasing seed yields. There are several challenges to increasing a number of female flowers: (i) manual hormone application to each inflorescence is laborious; (ii) hormone application is not economical; (iii) optimized hormone concentration at one environmental condition may not show the same efficiency under different environmental conditions; (iv) flowering and fruit maturity are not synchronized; and the $(\mathrm{v})$ variation in fruiting rate. Genetic modification of flowering genes or overexpression of genes involved in suppression of male flowers may enable us to overcome these challenges by allowing more female flowers to develop. Other possibilities include enhancing cytokinin synthesis by overexpressing genes associated with cytokinin biosynthesis or suppressing cytokinin breakdown by gene silencing or mutagenesis. Additionally, further research could be carried out on the effect of central carbon flow on the fruiting rate.

\section{CONCLUSION AND PERSPECTIVE}

The female to male floral ratio plays a significant role in deciding Jatropha's seed yield. Cytokinin application showed promising results in enhancing the ratio between female and male flowers. Promising approaches to increase the number of female flowers may be to induce the transitioning of male type inflorescences to the middle/intermediate type or to increase male flower abortion rates to allow female flowers to develop. Therefore, genes involved in female flowering or the abortion of male flowers could be targeted for the purpose of increasing female flowers in Jatropha. 


\section{AUTHOR CONTRIBUTIONS}

MG and JS conceived and designed the review manuscript, wrote, read, and approved the manuscript. JS contributed materials or analytical tools and supervised the work.

\section{REFERENCES}

Abdelgadir, H. A., Jager, A. K., Johnson, S. D., and Van, S. J. (2010). Influence of plant growth regulators on flowering, fruiting, seed oil content, and oil quality of Jatropha curcas. South Afr. J. Bot. 76, 440-444.

Achten, W. M. J., Verchot, L., Franken, Y. J., Mathijs, E., Singh, V. P., Aerts, R., et al. (2008). Jatropha bio-diesel production and use. Biomass Bioenergy 32, 1063-1084. doi: 10.1016/j.biombioe.2008.03.003

Acosta, I. F., Laparra, H., Romero, S. P., Schmelz, E., Hamberg, M., Mottinger, J. P., et al. (2009). Tasselseed 1 is a lipoxygenase affecting jasmonic acid signaling in sex determination of maize. Science 323, 262-265. doi: 10.1126/science.1164645

Adam, H., Jouannic, S., Morcillo, F., Verdeil, J. L., Duval, Y., and Tregear, J. W. (2007). Determination of flower structure in elaeisguineensis: do palms use the same homeotic genes as other species? Ann. Bot. 100, 1-12. doi: 10.1093/aob/ $\mathrm{mcm} 027$

Adriano-Anaya, M de. L., Pérez-Castillo, E., Salvador-Figueroa, M., Ruiz-González, S., Vázquez-Ovando, A., Grajales-Conesa, J., et al. (2016). Sex expression and floral diversity in Jatropha curcas: a population study in its center of origin. PeerJ 4:e2071. doi: $10.7717 /$ peerj.2071

Ainsworth,. C. (1999). Sex Determination in Plants. Oxford: BIOS Scientific Publishers

Ainsworth, C. (2000). Boys and girls come out to play: the molecular biology of dioecious plants. Ann. Bot. 86, 211-221. doi: 10.1006/anbo.2000.1201

Alvarez, J., and Smyth, D. R. (1999). CRABS CLAW and SPATULA, two Arabidopsis genes that control carpel development in parallel with AGAMOUS. Development 126, 2377-2386.

Bartley, G. E., and Ishida, B. K. (2007). Ethylene-sensitive and insensitive regulation of transcription factor expression during in vitro tomato sepal ripening. J. Exp. Bot. 58, 2043-2051. doi: 10.1093/jxb/erm075

Bentolila, S., Alfonso, A. A., and Hanson, M. R. (2002). A pentatricopeptide repeatcontaining gene restores fertility to cytoplasmic male-sterile plants. Proc. Natl. Acad. Sci. U.S.A. 99, 10887-10892. doi: 10.1073/pnas.102301599

Brownfield, L., Hafidh, S., Durbarry, A., Khatab, H., Sidorova, A., Doerner, P., et al. (2009). Arabidopsis DUO POLLEN3 is a key regulator of male germline development and embryogenesis. Plant Cell 21, 1940-1956. doi: 10.1105/tpc. 109.066373

Brunner, A. M., Rottmann, W. H., Sheppard, L. A., Krutovskii, K., DiFazio, S. P., Leonardi, S., et al. (2000). Structure and expression of duplicate AGAMOUS orthologues in poplar. Plant Mol. Biol. 44, 619-634.

Cecchetti, V., Altamura, M. M., Falasca, G., Costantino, P. P., and Cardarelli, M. (2008). Auxin regulates Arabidopsis anther dehiscence, pollen maturation, and filament elongation. Plant Cell 20, 1760-1774. doi: 10.1105/tpc.107.057570

Chen, M. S., Pan, B. Z., Fu, Q., Tao, Y. B., Martínez-Herrera, J., Niu, L., et al. (2017). Comparative transcriptome analysis between gynoecious and monoecious plants identifies regulatory networks controlling sex determination in Jatropha curcas. Front Plant Sci. 7:1953.

Chen, M. S., Pan, B. Z., Wang, G. J., Ni, J., Niu, L., and Xu, Z. F. (2014). Analysis of the transcriptional responses in inflorescence buds of Jatropha curcas exposed to cytokinin treatment. BMC Plant Biol. 14:318.

Chen, Y.-T., Chang, C.-C., Chen, C.-W., Chen, K.-C., and Chu, Y.-W. (2019). MADS-Box gene classification in angiosperms by clustering and machine learning approaches. Front Genet. 9:707. doi: 10.3389/fgene.2018.00707

Cheng, Y., Dai, X., and Zhao, Y. (2006). Auxin biosynthesis by the YUCCA flavin monooxygenases controls the formation of floral organs and vascular tissues in Arabidopsis. Genes Dev. 20, 1790-1799. doi: 10.1101/gad.1415106

Chu, Z., Yuan, M., Yao, J., Ge, X., Yuan, B., Xu, C., et al. (2006). Promoter mutations of an essential gene for pollen development result in disease resistance in rice. Genes Dev. 20, 1250-1255. doi: 10.1101/gad.1416306

Deng, Y., Wang, W., Li, W. Q., Xia, C., Liao, H. Z., Zhang, X. Q., et al. (2010). MALE GAMETOPHYTE DEFECTIVE 2, encoding a sialyltransferase-like

\section{ACKNOWLEDGMENTS}

We are thankful to the Department of Biotechnology and Bioinformatics, Jaypee University of Information Technology, Solan, India, for the providing facilities.

protein, is required for normal pollen germination and pollen tube growth in Arabidopsis. J. Integr. Plant Biol. 52, 829-843. doi: 10.1111/j.1744-7909.2010. 00963.x

Duan, Q., Wang, D., Xu, Z., and Bai, S. (2008). Stamen development in Arabidopsis is arrested by organ-specific overexpression of a cucumber ethylene synthesis gene CsACO2. Planta 228, 537-543. doi: 10.1007/s00425-008-0756-7

Favaro, R., Pinyopich, A., Battaglia, R., Kooiker, M., Borghi, L., Dittam, G., et al. (2003). MADS-box protein complexes control carpel and ovule development in Arabidopsis. Plant Cell 15, 2603-2611. doi: 10.1105/tpc.015123

Gangwar, M., Shankar, J., and Chauhan, R. S. (2018). Genomics of Female Flowering and Seed Yield in Jatropha Curcas L. Ph.D. Thesis, Jaypee University of Information Technology, Solan.

Golovkin, M., and Reddy, A. S. (2003). A calmodulin-binding protein from Arabidopsis has an essential role in pollen germination. Proc. Natl. Acad. Sci. U.S.A. 100, 10558-10563. doi: 10.1073/pnas.1734110100

Gross, T., Broholm, S., and Becker, A. (2018). CRABS CLAW acts as a bifunctional transcription factor in flower development. Front. Plant Sci. 9:835. doi: 10.3389/ fpls.2018.00835

Guo, J., Liu, C., Wang, P., Cheng, Q., Sun, L., Yang, W., et al. (2018). The aborted microspores (AMS)-like gene is required for anther and microspore development in pepper (Capsicum annuum L.). Int. J. Mol. Sci. 19:1341. doi: 10.3390/ijms19051341

Honma, T., and Goto, K. (2001). Complexes of MADS-box proteins are sufficient to convert leaves into floral organs. Nature 409, 525-529. doi: 10.1038/35054083

Hu, Y. X., Tao, Y. B., and Xu, Z. F. (2017). Overexpression of Jatropha Gibberellin 2-oxidase 6 (JcGA2ox6) induces dwarfism and smaller leaves, flowers and fruits in Arabidopsis and Jatropha. Front. Plant Sci. 8:2103.

Huang, J., Li, Z., and Zhao, D. (2016). Deregulation of the OsmiR160 target gene OsARF18 causes growth and developmental defects with an alteration of auxin signaling in rice. Sci. Rep. 6:29938.

Hui, W., Yang, Y., Wu, G., Peng, C., Chen, X., and Zayed, M. Z. (2017). Transcriptome profile analysis reveals the regulation mechanism of floral sex differentiation in Jatropha curcas L. Sci. Rep. 7:16421.

Hui, W. K., Wang, Y., Chen, X. Y., Zayed, M. Z., and Wu, G. J. (2018). Analysis of transcriptional responses of the inflorescence meristems in Jatropha curcas following gibberellin treatment. Int. J. Mol. Sci. 19:432. doi: 10.3390/ ijms19020432

Imaizumi, T. (2010). Arabidopsis circadian clock and photoperiodism: time to think about location. Curr. Opin. Plant Biol. 13, 83-89. doi: 10.1016/j.pbi.2009. 09.007

Ito, T., Ng, K. H., Lim, T. S., Yu, H., and Meyerowitz, E. M. (2007). The homeotic protein AGAMOUS controls late stamen development by regulating a jasmonate biosynthetic gene in Arabidopsis. Plant Cell 19, 3516-3529. doi: 10.1105/tpc.107.055467

Joshi, G., Shukla, A., and Shukla, A. (2011). Synergistic response of auxin and ethylene on physiology of Jatropha curcas L. Braz. J. Plant Physiol. 23, 66-77. doi: 10.1590/s1677-04202011000100009

Karlgren, A., Gyllenstrand, N., Clapham, D., and Lagercrantz, U. (2013). FLOWERING LOCUS T/TERMINAL FLOWER1-like genes affect growth rhythm and bud set in Norway spruce. Plant Physiol. 163, 792-803. doi: 10. 1104/pp.113.224139

Kater, M. M., Franken, J., Carney, K., Colombo, L., and Angenent, G. C. (2001). Sex determination in the monoecious species cucumber is confined to specific floral whorls. Plant Cell 13, 481-493. doi: 10.1105/tpc.13.3.481

Kumar, A., and Sharma, S. (2008). An evaluation of multipurpose oil seed crop for industrial uses (Jatropha curcas L): a review. Ind. Crops Prod. 28, 1-10. doi: 10.1016/j.indcrop.2008.01.001

Kurakawa, T., Ueda, N., Maekawa, M., Kobayashi, K., Kojima, M., Nagato, Y., et al. (2007). Direct control of shoot meristem activity by a cytokinin-activating enzyme. Nature 445:652. doi: 10.1038/nature05504 
Leseberg, C. H., Li, A. L., Kang, H., Duvall, M., and Mao, L. (2006). Genome-wide analysis of the MADS-box gene family in Populus trichocarpa. Gene 378, 84-94. doi: 10.1016/j.gene.2006.05.022

Li, C., Fu, Q., Niu, L., Luo, L., Chen, J., and Xu, Z. F. (2017). Three TFL1 homologues regulate floral initiation in the biofuel plant Jatropha curcas. Sci. Rep. 7:43090.

Li, C., Luo, L., Fu, Q., Niu, L., and Xu, Z. F. (2014). Isolation and functional characterization of JcFT, a flowering LOCUS T (FT) homologous gene from the biofuel plant Jatropha curcas. BMC Plant Biol. 14:125. doi: 10.1186/1471-222914- 125

Li, C., Schilmiller, A. L., Liu, G., Lee, G. I., Jayanty, S., Sageman, C., et al. (2005). Role of $\beta$-oxidation in jasmonate biosynthesis and systemic wound signaling in tomato. Plant Cell 17, 971-986. doi: 10.1105/tpc.104.029108

$\mathrm{Li}$, J., and Li, Q. (2009). The correlationship between flowering sequence and floral gender in the inflorescence of Jatropha curcas L. (Euphorbiaceae). J. Trop. Subtrop. Bot. 17, 1-4.

Li, X. G., Su, Y. H., Zhao, X. Y., Li, W., Gao, X. Q., and Zhang, X. S. (2010). Cytokinin overproduction caused alteration of flower development is partially mediated by CUC2 and CUC3 in Arabidopsis. Gene 450, 109-120. doi: 10.1016/ j.gene.2009.11.003

Liu, X., Huang, J., Parameswaran, S., Ito, T., Seubert, B., Auer, M., et al. (2009). The SPOROCYTELESS/NOZZLE gene is involved in controlling stamen identity in Arabidopsis. Plant Physiol. 151, 1401-1411. doi: 10.1104/pp.109. 145896

Luo, C., Li, K., Chen, Y., and Yong, S. (2007). Floral display and breeding system of Jatropha curcas L. Forest Stud. China 9, 114-119. doi: 10.1007/s11632-0070017-z

Maier, A. T., Stehling-Sun, S., Wollmann, H., Demar, M., Hong, R. L., Haubeiss, S., et al. (2009). Dual roles of the bZIP transcription factor PERIANTHIA in the control of floral architecture and homeotic gene expression. Development 136, 1613-1620. doi: 10.1242/dev.033647

Makkena, S., Lee, E., Sack, F. D., and Lamb, R. S. (2012). The R2R3 MYB transcription factors four lips and myb88 regulate female reproductive development. J. Exp. Bot. 63, 5545-5558. doi: 10.1093/jxb/ers209

Martínez-Fernández, I., Sanchís, S., Marini, N., Balanzá, V., Ballester, P., NavarreteGómez, J., et al. (2014). The effect of NGATHA altered activity on auxin signaling pathways within the Arabidopsis gynoecium. Front. Plant Sci. 5:210.

Mizoguchi, T., Wright, L., Fujiwara, S., and Cremer, F. (2005). Coupland, distinct roles of GIGANTEA in promoting flowering and regulating circadian rhythms in Arabidopsis. Plant Cell 17, 2255-2270. doi: 10.1105/tpc.105.033464

Nakamura, T., Schuster, G., Sugiura, M., and Sugita, M. (2004). Chloroplast RNA binding and pentatricopeptide repeat proteins. Biochem. Soc. Trans. 32, 571-574. doi: 10.1042/bst0320571

Pan, B. Z., and Xu, Z. F. (2011). Benzyladenine treatment significantly increases the seed yield of the biofuel plant Jatropha curcas. J. Plant Growth Regul. 30, 166-174. doi: 10.1007/s00344-010-9179-3

Pan, B. Z., Chen, M. S., Ni, J., and Xu, Z. F. (2014). Transcriptome of the inflorescence meristems of the biofuel plant Jatropha curcas treated with cytokinin. BMC Genomics 15:974. doi: 10.1186/1471-216415-974

Park, J. H., Halitschke, R., Kim, H. B., Baldwin, I. T., Feldmann, K. A., and Feyereisen, R. (2002). A knock-out mutation in allene oxide synthase results in male sterility and defective wound signal transduction in Arabidopsis due to a block in jasmonic acid biosynthesis. Plant J. 31, 1-12. doi: 10.1046/j.1365313x.2002.01328.x

Parěnicová, L., de Folter, S., Kieffer, M., Horner, D. S., Favalli, C., Busscher, J., et al. (2003). Molecular and phylogenetic analyses of the complete MADS-box transcription factor family in Arabidopsis: new openings to the MADS world. Plant Cell 15, 1538-1551. doi: 10.1105/tpc.011544

Pelaz, S., Ditta, G. S., Baumann, E., Wisman, E., and Yanofsky, M. F. (2000). B and $\mathrm{C}$ floral organ identity functions require SEPALLATA MADS-box genes. Nature 405, 200-203. doi: 10.1038/35012103

Pinyopich, A., Ditta, G. S., Savidge, B., Liljegren, S. J., Baumann, E., Wisman, E., et al. (2003). Assessing the redundancy of MADS-box genes during carpel and ovule development. Nature 424, 85-88. doi: 10.1038/nature01741

Prunet, N., Yang, W., Das, P., Meyerowitz, E. M., and Jack, T. P. (2017). SUPERMAN prevents class B gene expression and promotes stem cell termination in the fourth whorl of Arabidopsis thaliana flowers. PNAS 114, 7166-7171. doi: 10.1073/pnas.1705977114

Ramos, M. J. N., Coito, J. L., Silva, H. G., Cunha, J., Costa, M. M. R., and Rocheta, M. (2014). Flower development and sex specification in wild grapevine. BMC Genomics 15:1095. doi: 10.1186/1471-2164-151095

Rodríguez-Concepción, M., and Beltrán, J. P. (1995). Repression of the pea lipoxygenase gene loxg is associated with carpel development. Plant Mol. Biol. 27, 887-899. doi: 10.1007/bf00037017

Roxrud, I., Lid, S. E., Fletcher, J. C., Schmidt, E. D., and Opsahl-Sorteberg, H. G. (2007). GASA4, one of the 14-member Arabidopsis GASA family of small polypeptides, regulates flowering and seed development. Plant Cell Physiol. 48, 471-483. doi: $10.1093 / \mathrm{pcp} / \mathrm{pcm} 016$

Salvador-Figueroa, M., Magaña-Ramos, J., Vázquez-Ovando, J. A., Adriano-Anaya, M. L., and Ovando-Medina, I. (2015). Genetic diversity and structure of Jatropha curcas L. in its centre of origin. Plant Genet Resourc. 13, 9-17. doi: $10.1017 /$ S 1479262114000550

Seesangboon, A., Gruneck, L., Pokawattana, T., Eungwanichayapant, P. D., Tovaranonte, J., and Popluechai, S. (2018). Transcriptome analysis of Jatropha curcas L. flower buds responded to the paclobutrazol treatment. Plant Physiol. Biochem. 127, 276-286. doi: 10.1016/j.plaphy.2018. 03.035

Shafiee, S., and Topal, E. (2009). When will fossil fuel reserves be diminished? Energy Pol. 37, 181-189. doi: 10.1016/j.enpol.2008.08.016

Stepanova, A. N., Robertson-Hoyt, J., Yun, J., Benavente, L. M., Xie, D.-Y., Dolezal, K., et al. (2008). TAA1-mediated auxin biosynthesis is essential for hormone crosstalk and plant development. Cell 133, 177-191. doi: 10.1016/j.cell.2008.01. 047

Stepanova, A. N., Yun, J., Robles, L. M., Novak, O., He, W., Guo, H., et al. (2011). The Arabidopsis YUCCA1 flavin monooxygenase functions in the indole-3pyruvic acid branch of auxin biosynthesis. Plant Cell 23, 3961-3973. doi: 10.1105/tpc.111.088047

Switzenberg, J., Little, H., Hammar, S., and Grumet, R. (2014). Floral primordiatargeted ACS (1-aminocyclopropane-1-carboxylate synthase) expression in transgenic Cucumis melo implicates fine tuning of ethylene production mediating unisexual flower development. Planta 240, 797-808. doi: 10.1007/ s00425-014-2118-y

Tang, M., Tao, Y. B., Fu, Q., Song, Y., Niu, L., and Xu, Z. F. (2016). An ortholog of LEAFY in Jatropha curcas regulates flowering time and floral organ development. Sci. Rep. 6:37306.

Ueguchi-Tanaka, M., Nakajima, M., Katoh, E., Ohmiya, H., Asano, K., Saji, S., et al. (2007). Molecular interactions of a soluble gibberellin receptor, GID1, with a Rice DELLA protein, SLR1, and gibberellins. Plant Cell 19, 2140-2155. doi: 10.1105/tpc.106.043729

Wang, D. H., Li, F., Duan, Q. H., Han, T., Xu, Z. H., and Bai, S. N. (2010). Ethylene perception is involved in female cucumber flower development. Plant J. 61, 862-872. doi: 10.1111/j.1365-313x.2009.04114.x

Werner, T., and Schmülling, T. (2009). Cytokinin action in plant development. Curr. Opin. Plant Biol. 12, 527-538. doi: 10.1016/j.pbi.2009.07.002

Wu, J., Liu, Y., Tang, L., Zhang, F., and Chen, F. (2011). A study on structural features in early flower development of Jatropha curcas L. and the classification of its inflorescence. Afr. J. Agric. Res. 6, 275-284.

Xu, G., Huang, J., Yang, Y., and Yao, Y. A. (2016). Transcriptome analysis of flower sex differentiation in Jatropha curcas L. using RNA sequencing. PLoS One 11:e0145613. doi: 10.1371/journal.pone.0145613

Xu, Y., Prunet, N., Gan, E. S., Wang, Y., Stewart, D., and Wellmer, F. (2018). SUPERMAN regulates floral whorl boundaries through control of auxin biosynthesis. EMBO J. 37:e97499.

Yamaki, S., Nagato, Y., Kurata, N., and Nonomura, K. (2011). Ovule is a lateral organ finally differentiated from the terminating floral meristem in rice. Dev. Biol. 351, 208-216. doi: 10.1016/j.ydbio.2010. 12.006

Yang, J., Yang, M. F., Wen, P. Z., Fan, C., and Shen, S. H. (2011). A putative flowering-time- related Dof transcription factor gene, JcDof3, is controlled by the circadian clock in Jatropha curcas. Plant Sci. 181, 667-674. doi: 10.1016/j.plantsci.2011.05. 003 
Ye, J., Geng, Y., Zhang, B., Mao, H., Qu, J., and Chua, N. H. (2014). The jatropha FT ortholog is a systemic signal regulating growth and flowering time. Biotechnol. Biofuels. 7:91.

Ye, Q., Zhu, W., Li, L., Zhang, S., Yin, Y., Ma, H., et al. (2010). Brassinosteroids control male fertility by regulating the expression of key genes involved in Arabidopsis anther and pollen development. Proc. Natl. Acad. Sci. U.S.A. 107, 6100-6105.

Zhu, J., Chen, H., Li, H., Gao, J. F., Jiang, H., Wang, C., et al. (2008). Defective in tapetal development and function 1 is essential for anther development and petal function for microspore maturation in Arabidopsis. Plant J. 55, 266-277. doi: 10.1111/j.1365-313X.2008.03500.x
Conflict of Interest: The authors declare that the research was conducted in the absence of any commercial or financial relationships that could be construed as a potential conflict of interest.

Copyright (๑) 2020 Gangwar and Shankar. This is an open-access article distributed under the terms of the Creative Commons Attribution License (CC BY). The use, distribution or reproduction in other forums is permitted, provided the original author(s) and the copyright owner(s) are credited and that the original publication in this journal is cited, in accordance with accepted academic practice. No use, distribution or reproduction is permitted which does not comply with these terms. 